\title{
TYPES OF LEISURE TIME ACTIVITIES AMONG LAJKONIK SNACKS COMPANY EMPLOYEES IN SKAWIN
}

\section{Robert Walaszek ${ }^{1}$, Tadeusz Kasperczyk², Grzegorz Gołąb ${ }^{3}$}

\author{
${ }^{1}$ Department of Biological Regeneration, University School of Physical Education in Cracow \\ ${ }^{2}$ Department of Physiotherapy and Biological Regeneration, University School of Physical Education in Cracow \\ ${ }^{3}$ Sports and Leisure Centre in Skawin
}

Walaszek R., Kasperczyk T., Gołąb G., (2014), Types of leisure time activities among Lajkonik snacks company employees in Skawin. Health Problems of Civilization 3 (8), p. 29-38

\begin{abstract}
Summary: Aim of study. The aim of this study is to evaluate the size and the types of leisure-time activities with special regard to health-oriented behaviors among blue-collar and white-collar workers of the snacks company "Lajkonik" in Skawin. Research material and methods. Questionnaire survey using original survey questionnaire was conducted among 60 people: 30 blue-collar and 30 white-collar workers of both sexes. The age of the respondents ranged between 18 and 65 years. The survey questions concerned: amount of leisure time, preferred types of health-oriented leisure activities, people (friends, family) who join respondents in leisure activities, most frequent leisure places and activities performed by respondents during leisure time. Chi-squared test was used to compare employees' preferences and leisure time habits.Findings. The survey showed that leisure time is seen as desired by employees - a decided majority of respondents felt the want of leisure time. It was observed that there was a difference between leisure time activities preferred by blue-collar workers and white-collar workers - white-collar workers preferred physical activities.

Conclusions. In comparison with blue-collar workers, white-collar workers more frequently chose active leisure pursuits, in particular qualified tourism and physical recreation whereas blue-collar workers participated in parties and social gatherings more.
\end{abstract}

Key words: work, leisure time, health, tourism, recreation

\section{Introduction}

Leisure time has accompanied people since the beginning of times. Leisure time habits play an important role in health promotion. Over the centuries leisure time activities, their amount and importance have undergone significant changes. The thing that has not changed is their existence essential for mental and physical health (Izdebska 1978, Kamiński 1965, Kędzior, Wawrzak-Chodaczek 2000, Winiarski 2011, Wnuk-Lipiński 1972). Researchers believe that functions of leisure time are as follows: energizing, developing, socializing, integrating and entertaining (Bombol, Dąbrowska 2003, Baudrillard 2006).

Literature indicates that there were many researchers who analyzed issues concerning leisure time habits (Przecławski 1993, Wolańska 1985, Jung 1989). Dębski (2009) presented research findings concerning "Leisure time habits among Gdańsk-Gdynia-Sopot Tricity inhabitants" conducted by the Regional Volunteer Centre in Gdańsk. The aim of this research was to define leisure time activities and how they corresponded to people's cultural and sports and recreation interests.

In turn, Kacperczyk (2004) from the Univeristy of Łódź conducted research which focused on activities performed by Łódź inhabitants during work and household chores-leisure time. The aim of Kacperczyk's experiment was to explore inhabitants' attitudes towards cultural offer presented by cultural institutions, local authorities and foundations for promotion of Łódź.

The aim of the study was comparative analysis of leisure time activities among blue-collar and white-collar workers of the foodstuffs company Lajkonik Snacks GmbH Sp. k. in Skawin. In order to achieve the above-mentioned aim the following research questions were asked:

1. Where and who do respondents usually spend their leisure time with?

2. What are respondents' preferred leisure time activities?

3. What are the differences in leisure time habits of blue-collar and white-collar workers?

Address for correspondence: Robert Walaszek, Department of Biological Regeneration, University School of Physical Education, 31-571 Kraków, Jana Pawła II 78 St., e-mail: robertwalaszek63@gmail.com, phone: (+48) 605-821-830

Tables: 11, Figures: 2, References: 19, Full text PDF www.hpc.edu.pl Copyright (c) Pope John Paul II State School of Higher Education in Biała Podlaska, Sidorska 95/97, 21-500 Biała Podlaska Indexation: Index Copernicus, Database AGRO, ProQuest, Polish Ministry of Science and Higher Education. This is an open-access article distributed under the terms of the Creative Commons Attribution Non-commercial License (http://creativecommons.org/licenses/by-nc/3.0), which permits use, distribution, and reproduction in any medium, provided the original work is properly cited, the use is non-commercial and is otherwise in compliance with the license. 


\section{Material and methods}

The research focused on the evaluation of leisure time habits among the employees of the foodstuffs company Lajkonik Snacks GmbH Sp.k. in Skawin. The research included the analysis of: jobs held by respondents, environmental conditions, age, assets, family situation and other factors affecting amount of leisure time and how it can be used. Respondents' individual preferences concerning leisure time habits were also analyzed.

For the purpose of research conducted in October 2013 a group of 60 employees between 18 and 65 years was used. Main sampling criterion was job held by respondents therefore 30 blue-collar workers and 30 white-collar workers were invited to participate in the research.

The research used original questionnaire survey. The questionnaire consisted of respondent's particulars and 11 questions which required one or several answers. The original survey questionnaire was used to help gain information about leisure time activities and show differences in this area resulting from jobs held by respondents. Questions included in the survey questionnaire concerned: amount of leisure time, preferred health-oriented leisure activities, information about where and who respondents spend their leisure time with. Chi-squared test was used to compare employees preferences concerning leisure time activities. Statistical significance level was: $\mathrm{p} \leq$ 0,05 (Ryłko 1989).

\section{Findings}

For the purpose of this research four age groups were defined for both sample groups (18-30; 31-40; 41-50; 51-65).

\section{Blue-collar workers}

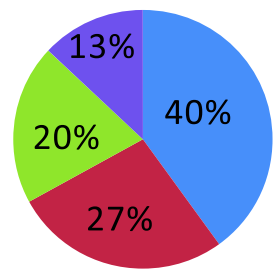

18-30 years old

31-40 years old

41-50 years old

51-65 years old

\section{White-collar workers}

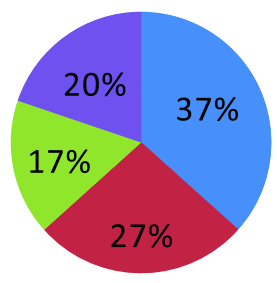

18-30 years old

31-40 years old

41-50 years old

51-65 years old

$\chi^{2}=0,957 ; \mathrm{df}=3, \mathrm{p}=0,8115$

Figure 1. Age groups - all respondents

It was indicated that both blue-collar and white-collar workers represented similar percentage in each age group, and observed differences were not statistically significant (Figure 1).

\section{Blue-collar workers}

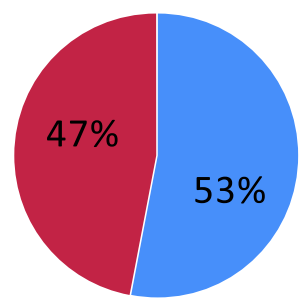

White-collar workers

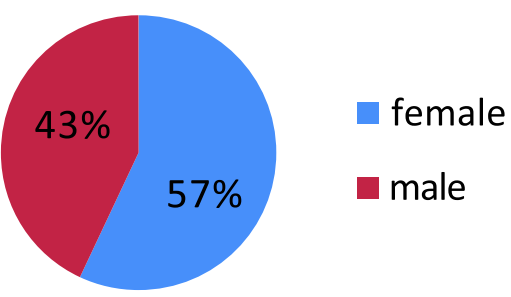

$$
\chi^{2}=0,135 ; \mathrm{df}=1, \mathrm{p}=0,712
$$

Figure 2. Gender - all respondents

In terms of gender, in both groups the percentage of females was higher but the differences were not statistically significant (Figure 2). 
Table 1. Respondents' leisure time on working days

\begin{tabular}{|l|c|c|c|c|}
\hline \multirow{2}{*}{ How much leisure time do you have on working days? } & \multicolumn{2}{|c|}{ Blue-collar workers } & \multicolumn{2}{|c|}{ White-collar workers } \\
\cline { 2 - 5 } & Number of people & $\%$ & Number of people & $\%$ \\
\hline I Don't have & 5 & 17 & 3 & 10 \\
\hline up to one hour & 6 & 20 & 8 & 27 \\
\hline 1-3 hours & 12 & 40 & 20 & 3 \\
\hline 3-6 hours & 6 & 3 & 2 & 14 \\
\hline over 6 hours & 1 & 20 & 6 \\
\hline
\end{tabular}

only one answer could be chosen

$$
\chi^{2}=5,619 ; \mathrm{df}=4, \mathrm{p}=0,2294
$$

(Table 1) $43 \%$ of all respondents had up to 3 hours of leisure time on working days but $13 \%$ of respondents claimed that they did not have any leisure time whereas $20 \%$ of respondents enjoyed over 3 hours of leisure time. No statistically significant differences were observed between blue-collar and white-collar workers as far as amount of leisure time on working days is concerned.

Table 2. Respondents' leisure time on holidays

\begin{tabular}{|l|c|c|c|c|}
\hline \multirow{2}{*}{ How much time do you have on holidays? } & \multicolumn{2}{|c|}{ Blue-collar workers } & \multicolumn{2}{|c|}{ White-collar workers } \\
\cline { 2 - 5 } & Number of people & $\%$ & Number of people & $\%$ \\
\hline I Don't have & 1 & 3 & 1 & 3 \\
\hline up to one hour & 4 & 13 & 1 & 3 \\
\hline 1-3 hours & 4 & 13 & 3 & 10 \\
\hline 3-6 hours & 10 & 34 & 11 & 37 \\
\hline over 6 hours & 11 & 37 & 14 & 47 \\
\hline
\end{tabular}

only one answer could be chosen

$$
\chi^{2}=4,733 ; \mathrm{df}=4, \mathrm{p}=0,1923
$$

(Table 2) On holidays 35\% of all respondents had 3-6 hours of leisure time and $42 \%$ of respondents had over 6 hours of leisure time. Blue-collar workers declared a little less leisure time on holidays but the differences were not statistically significant.

Table 3. Leisure places chosen by respondents

\begin{tabular}{|l|c|c|c|c|}
\hline \multirow{2}{*}{ Where do you usually spend your leisure time? } & \multicolumn{2}{|c|}{ Blue-collar workers } & \multicolumn{2}{|c|}{ White-collar workers } \\
\cline { 2 - 5 } & Number of people & $\%$ & Number of people & $\%$ \\
\hline at home & 21 & 70 & 17 & 57 \\
\hline outside the house but within the place of residence & 3 & 10 & 12 & 40 \\
\hline outside the place of residence & 6 & 20 & 1 & 3 \\
\hline
\end{tabular}

only one answer could be chosen

$$
\chi^{2}=9,392 ; \mathrm{df}=2, \mathrm{p}=0,0091
$$

(Table 3) Both blue-collar and white-collar workers of Lajkonik company preferred to spend their leisure time at home (70\% and 57\% respectively). It was observed that blue-collar workers chose to leave their places of residence more often (20\%). Differences between the two groups in preferred leisure places were statistically significant. 
Table 4. Respondents' favourite leisure activities

\begin{tabular}{|l|c|c|c|c|}
\hline \multirow{2}{*}{ What are your favourite leisure activities? } & \multicolumn{2}{|c|}{ Blue-collar workers } & \multicolumn{2}{c|}{ White-collar workers } \\
\cline { 2 - 4 } & Number of people & $\%$ & Number of people & $\%$ \\
\hline Tourism & 17 & 57 & 26 & 87 \\
\hline Physical recreation & 11 & 37 & 18 & 60 \\
\hline Means of transport & 15 & 50 & 21 & 70 \\
\hline Cultural institutions & 1 & 3 & 7 & 23 \\
\hline $\begin{array}{l}\text { Self-education (not connected with career; on their own } \\
\text { initiative; in fields of culture, arts, science) }\end{array}$ & 2 & 7 & 4 & 13 \\
\hline $\begin{array}{l}\text { DIY (carpentry, smithery, locksmithing, crochet, embroidery, } \\
\text { sewing) }\end{array}$ & 7 & 23 & 15 & 50 \\
\hline Amateur breeding (animal and plant breeding) & 5 & 17 & 9 & 30 \\
\hline $\begin{array}{l}\text { Social activity (acting for society, apart from duties at work or } \\
\text { at home) }\end{array}$ & 0 & 0 & 7 & 23 \\
\hline Social life (social gatherings, parties) & 13 & 43 & 10 & 33 \\
\hline
\end{tabular}
many answers could be chosen

$$
\chi^{2}=36,919 ; \mathrm{df}=8, \mathrm{p}=0,001
$$

There were clear statistically significant differences between sample groups in terms of participation in tourism and physical recreation. The research showed that more white-collar workers than blue-collar workers chose these types of activity (table 4). Among white-collar workers $87 \%$ declared going in for tourism and $60 \%$ for physical recreation. Among blue-collar workers it was $57 \%$ and $37 \%$ respectively.

Table 5. Types of tourism among respondents

\begin{tabular}{|c|c|c|c|c|}
\hline \multirow{2}{*}{ If you go in for tourism, choose the type: } & \multicolumn{2}{|c|}{ Blue-collar workers } & \multicolumn{2}{|c|}{ White-collar workers } \\
\hline & Number of people & $\%$ & Number of people & $\%$ \\
\hline $\begin{array}{l}\text { Heritage tourism (discovering new elements of environment, rituals } \\
\text { and lifestyles) }\end{array}$ & 2 & 7 & 5 & 17 \\
\hline $\begin{array}{l}\text { Qualified tourism (skiing, snowboard, climbing, diving, canoeing, } \\
\text { yachting, cycling etc.) }\end{array}$ & 4 & 13 & 12 & 40 \\
\hline Recreation tourism (holidays, weekend trips, cycling trips) & 13 & 43 & 22 & 73 \\
\hline Health tourism (sanatoriums, health-resorts) & 0 & 0 & 1 & 3 \\
\hline Religious tourism (pilgrimages, visiting holy sites) & 7 & 23 & 1 & 3 \\
\hline
\end{tabular}

many answers could be chosen

$$
\chi^{2}=9,516 ; \mathrm{df}=4, \mathrm{p}=0,0494
$$

There were clear statistically significant differences between sample groups in terms of preferred types of tourism. The most favorite types of tourism among white-collar workers were qualified tourism (40\%) and recreation tourism (73\%) whereas blue-collar workers chose recreation tourism (43\%) and religious tourism (23\%) (table 5).

Table 6. Frequency of travel - all respondents

\begin{tabular}{|l|c|c|c|c|}
\hline \multicolumn{5}{|l|}{ How often do you travel? } \\
\hline \multirow{2}{*}{ Qualified tourism } & Blue-collar workers & several times a week & several times a year & less often \\
\cline { 2 - 5 } & White-collar workers & 2 & 3 & 1 \\
\hline \multirow{2}{*}{ Recreation tourism } & Blue-collar workers & 4 & 6 & 2 \\
\cline { 2 - 5 } & White-collar workers & 3 & 6 & 5 \\
\hline
\end{tabular}

many answers could be chosen

qualified tourism $\chi^{2}=3,000 ; \mathrm{df}=2, \mathrm{p}=0,2231$

recreation tourism $\chi^{2}=3,442 ; \mathrm{df}=2, \mathrm{p}=0,1788$ 
There was similar frequency of travelling among both groups of respondents. Half of respondents travelled several times a year, and as often or less often they participated in camping, cycling trips or holidays. Differences between the two groups were not statistically significant. (Table 6).

Table 7. Types of recreation tourism among respondents

\begin{tabular}{|l|c|c|c|c|}
\hline \multirow{2}{*}{ If you go in for recreation tourism, choose the type: } & \multicolumn{2}{|c|}{ Blue-collar workers } & \multicolumn{2}{c|}{ White-collar workers } \\
\cline { 2 - 5 } & Number of people & $\%$ & Number of people & $\%$ \\
\hline A walk in the open air & 12 & 40 & 17 & 57 \\
\hline Cycling & 10 & 33 & 17 & 57 \\
\hline Working in the country-side & 14 & 47 & 12 & 40 \\
\hline Aerobics & 3 & 10 & 2 & 7 \\
\hline Training at the gym & 4 & 13 & 1 & 3 \\
\hline Swimming & 9 & 30 & 19 & 63 \\
\hline Jogging & 0 & 0 & 3 & 10 \\
\hline dancing & 0 & 0 & 2 & 7 \\
\hline other & 12 & 40 & 3 & 10 \\
\hline
\end{tabular}

many answers could be chosen

$$
\chi^{2}=17,905 ; \mathrm{df}=8, \mathrm{p}=0,0219
$$

The research and the findings show that respondents of both groups chose different forms of physical recreation. Considerable and statistically significant differences are observed between blue-collar and white-collar workers in terms of their attitude to going for a walk, swimming or cycling. Among white-collar workers 57\% declared walks in the open air, 63\% swimming and 57\% cycling. Among blue-collar workers it was $40 \%, 30 \%$ and $33 \%$ respectively (table 7 ).

Table 8. Amount of time devoted to physical recreation - all respondents

\begin{tabular}{|l|c|c|c|c|}
\hline \multicolumn{2}{|l}{ How much time do you devote to recreation? } & several times a week & several times a month & Less often \\
\hline \multirow{2}{*}{ cycling } & Blue-collar workers & 2 & 3 & 5 \\
\cline { 2 - 5 } & White-collar workers & 5 & 8 & 4 \\
\hline \multirow{2}{*}{ swimming } & Blue-collar workers & 1 & 4 & 4 \\
\cline { 2 - 5 } & White-collar workers & 1 & 12 & 6 \\
\hline \multirow{2}{*}{ working in the country-side } & Blue-collar workers & 9 & 5 & 0 \\
\cline { 2 - 5 } & White-collar workers & 7 & 4 & 0 \\
\hline \multirow{2}{*}{ A walk in the open air } & Blue-collar workers & 8 & 6 & 0 \\
\cline { 2 - 5 } & White-collar workers & 11 & 5 & 0 \\
\hline
\end{tabular}

Multiple answers could be chosen

$$
\text { cycling } \chi^{2}=5,175 ; \mathrm{df}=2, \mathrm{p}=0,0752
$$

swimming $\chi^{2}=6,000 ; \mathrm{df}=2, \mathrm{p}=0,0497$

working in the country $\chi^{2}=0,571 ; \mathrm{df}=1, \mathrm{p}=0,4496$

strolling in the open air $\mathrm{c}^{2}=1,484 ; \mathrm{df}=1, \mathrm{p}=0,2230$

It was indicated that majority of white-collar workers declared cycling several times a week or several times a month. Blue-collar workers showed less interest in this activity but differences between the groups were not statistically significant.

More than twice as many white-collar workers chose swimming (table 7) and much more often than blue-collar workers (table 8). Differences between sample groups were statistically significant. There were no statistically significant differences in amount of time devoted to spending time in the country between respondents of both groups who declared this activity. There were also no statistically significant differences between the two groups in amount of time devoted to going for a walk in the open air. 
Table 9. The amount of leisure time devoted to the media - in general

\begin{tabular}{|c|c|c|c|c|c|c|c|}
\hline \multicolumn{8}{|c|}{ How much leisure time do you devote daily to the media listed below? } \\
\hline & & & not at all & up to 1 hour & $\begin{array}{c}\text { from } \\
1 \text { to } 3 \text { hours }\end{array}$ & $\begin{array}{c}\text { from } \\
3 \text { to } 6 \text { hours }\end{array}$ & $\begin{array}{c}\text { over } \\
6 \text { hours }\end{array}$ \\
\hline \multirow{4}{*}{ the Internet } & \multirow[t]{2}{*}{ Blue-collar workers } & $\begin{array}{l}\text { Number } \\
\text { of people }\end{array}$ & 6 & 14 & 7 & 1 & 2 \\
\hline & & $\%$ & 20 & 47 & 23 & 3 & 7 \\
\hline & \multirow[t]{2}{*}{ White-collar workers } & $\begin{array}{l}\text { Number } \\
\text { of people }\end{array}$ & 1 & 17 & 11 & 1 & 0 \\
\hline & & $\%$ & 3 & 57 & 37 & 3 & 0 \\
\hline \multirow{4}{*}{ the press } & \multirow[t]{2}{*}{ Blue-collar workers } & $\begin{array}{l}\text { Number } \\
\text { of people }\end{array}$ & 12 & 18 & 0 & 0 & 0 \\
\hline & & $\%$ & 40 & 60 & 0 & 0 & 0 \\
\hline & \multirow{2}{*}{ White-collar workers } & $\begin{array}{l}\text { Number } \\
\text { of people }\end{array}$ & 13 & 17 & 0 & 0 & 0 \\
\hline & & $\%$ & 43 & 57 & 0 & 0 & 0 \\
\hline \multirow{4}{*}{ books } & \multirow[t]{2}{*}{ Blue-collar workers } & $\begin{array}{l}\text { Number } \\
\text { of people }\end{array}$ & 14 & 16 & 0 & 0 & 0 \\
\hline & & $\%$ & 47 & 53 & 0 & 0 & 0 \\
\hline & \multirow[t]{2}{*}{ White-collar workers } & \begin{tabular}{|c|}
$\begin{array}{c}\text { Number of } \\
\text { people }\end{array}$ \\
\end{tabular} & 8 & 18 & 3 & 1 & 0 \\
\hline & & $\%$ & 27 & 60 & 10 & 3 & 0 \\
\hline \multirow{4}{*}{ radio } & \multirow[t]{2}{*}{ Blue-collar workers } & \begin{tabular}{|c|}
$\begin{array}{c}\text { Number of } \\
\text { people }\end{array}$ \\
\end{tabular} & 8 & 9 & 4 & 9 & 0 \\
\hline & & $\%$ & 27 & 30 & 13 & 30 & 0 \\
\hline & \multirow[t]{2}{*}{ White-collar workers } & \begin{tabular}{|c|}
$\begin{array}{c}\text { Number of } \\
\text { people }\end{array}$ \\
\end{tabular} & 5 & 12 & 9 & 2 & 2 \\
\hline & & $\%$ & 16 & 40 & 30 & 7 & 7 \\
\hline \multirow{4}{*}{ TV } & \multirow[t]{2}{*}{ Blue-collar workers } & \begin{tabular}{|c|}
$\begin{array}{c}\text { Number of } \\
\text { people }\end{array}$ \\
\end{tabular} & 3 & 12 & 11 & 3 & 1 \\
\hline & & $\%$ & 10 & 40 & 37 & 10 & 3 \\
\hline & \multirow[t]{2}{*}{ White-collar workers } & \begin{tabular}{|c|}
$\begin{array}{c}\text { Number of } \\
\text { people }\end{array}$ \\
\end{tabular} & 2 & 10 & 18 & 0 & 0 \\
\hline & & $\%$ & 7 & 33 & 60 & 0 & 0 \\
\hline
\end{tabular}

Respondents could choose more than one answer.

Leisure time spent on the Internet $\chi^{2}=6,750 ; \mathrm{df}=4, \mathrm{p}=0,1496$

Leisure time spent on reading the press $\chi^{2}=0,135 ; \mathrm{df}=1, \mathrm{p}=0,7125$

Leisure time spent on reading books $\chi^{2}=8,722 ; \mathrm{df}=3, \mathrm{p}=0,0332$

Leisure time spent on listening to radio $\chi^{2}=9,498 ; \mathrm{df}=4, \mathrm{p}=0,0497$

Leisure time spent in front of the $\mathrm{TV} \chi^{2}=6,071 ; \mathrm{df}=4, \mathrm{p}=0,1938$

It was observed, that the majority of respondents used the Internet, whereas at least every fifth person working as a blue-collar worker did not do that, but the difference between the blue- and white-collar workers was not statistically significant. Respondents were very reluctant to read the press and newspapers, and over $40 \%$ both the blue-, and white-collar workers did not read the press at all. Nearly half of the blue-collar workers did not read books at all. The people surveyed often listened to radio mainly for up to 3 hours a day. Not many respondents resigned from watching TV. Numbers indicate, that about $96 \%$ of all workers devoted up to 3 hours a day to watching TV (Table 9). 
Table 10. Frequency of visiting cultural institutions by respondents

\begin{tabular}{|c|c|c|c|c|c|c|}
\hline \multicolumn{7}{|c|}{ How often do you visit cultural institutions? } \\
\hline & & & once a week & once a month & once a year & not at all \\
\hline \multirow{4}{*}{ theatre } & \multirow{2}{*}{ Blue-collar workers } & Number of people & 0 & 0 & 5 & 25 \\
\hline & & $\%$ & 0 & 0 & 17 & 83 \\
\hline & \multirow{2}{*}{ White-collar workers } & Number of people & 0 & 0 & 10 & 20 \\
\hline & & $\%$ & 0 & 0 & 33 & 67 \\
\hline \multirow{4}{*}{ philharmonic } & \multirow{2}{*}{ Blue-collar workers } & Number of people & 0 & 0 & 0 & 30 \\
\hline & & $\%$ & 0 & 0 & 0 & 100 \\
\hline & \multirow{2}{*}{ White-collar workers } & Number of people & 0 & 0 & 0 & 30 \\
\hline & & $\%$ & 0 & 0 & 0 & 100 \\
\hline \multirow{4}{*}{ museum } & \multirow{2}{*}{ Blue-collar workers } & Number of people & 0 & 0 & 7 & 23 \\
\hline & & $\%$ & 0 & 0 & 23 & 77 \\
\hline & \multirow{2}{*}{ White-collar workers } & Number of people & 0 & 0 & 9 & 21 \\
\hline & & $\%$ & 0 & 0 & 30 & 70 \\
\hline \multirow{4}{*}{ exhibitions } & \multirow{2}{*}{ Blue-collar workers } & Number of people & 0 & 0 & 8 & 22 \\
\hline & & $\%$ & 0 & 0 & 27 & 73 \\
\hline & \multirow{2}{*}{ White-collar workers } & Number of people & 0 & 0 & 11 & 19 \\
\hline & & $\%$ & 0 & 0 & 37 & 63 \\
\hline
\end{tabular}

Respondents could choose more than one answer.

The theatre plays $\chi^{2}=3,75 ; \mathrm{df}=1, \mathrm{p}=0,0528$

Visiting museums $\chi^{2}=0,634 ; \mathrm{df}=1, \mathrm{p}=0,4255$

Taking part in exhibitions $\chi^{2}=1,291 ; \mathrm{df}=1, \mathrm{p}=0,2557$

Based on the survey results it was established that workers of Lajkonik did not go to the theatre at all, or did it very rarely. It was observed, that this way of spending leisure time once a year was chosen by $17 \%$ of the bluecollar workers, and 33\% of the white-collar workers. The survey also showed, that none of respondents went to the philharmonic in their leisure time. 23\% of the blue-collar workers, and 30\% of the white-collar workers once a week went to the museum. Similarly, representatives of the two surveyed groups rarely visited exhibitions. (Table 10).

Table 11. Leisure time devoted to parties, or social contacts

\begin{tabular}{|l|l|c|c|c|c|}
\hline \multicolumn{6}{|c|}{ How often do you go to parties, or devote your leisure time to social contacts? } \\
\hline \multirow{3}{*}{ disco } & & every day & a few times a week & a few times a month & less frequently \\
\hline \multirow{3}{*}{ clubs/cafes } & Blue-collar workers & 0 & 0 & 2 & 15 \\
\cline { 2 - 6 } & White-collar workers & 0 & 0 & 1 & 6 \\
\hline \multirow{3}{*}{ meeting friends } & Blue-collar workers & 0 & 0 & 4 & 13 \\
\cline { 2 - 6 } & White-collar workers & 0 & 0 & 5 & 10 \\
\hline \multirow{3}{*}{ meeting family } & White-collar workers & 0 & 5 & 9 & 15 \\
\cline { 2 - 6 } & Blue-collar workers & 7 & 6 & 11 & 18 \\
\cline { 2 - 6 } & White-collar workers & 1 & 16 & & 3 \\
\hline
\end{tabular}

Respondents could choose more than one answer.

Leisure time spent in a disco $\chi^{2}=14,5 ; \mathrm{df}=1, \mathrm{p}=0,0001$

Leisure time spent in a club or café $\chi^{2}=1,1 ; \mathrm{df}=1, \mathrm{p}=0,2942$

Leisure time spent with friends $\chi^{2}=13,5 ; \mathrm{df}=2, \mathrm{p}=0,0011$

Leisure time spent with family $\chi^{2}=9,847 ; d f=3, p=0,0199$ 
Based on results of the survey it was revealed, that respondents working physically more often than the whitecollar workers chose parties, and social contacts, such as meetings and discos in their leisure time. differences between the groups surveyed are statistically significant (Table 11). It was indicated, that a similar number of the blue-, and white-collar workers visited clubs, and cafes. People working physically devoted leisure time to social contacts more often (a few time a week, or a month). In this example, differences are statistically significant. Regardless the character of work performed, workers took part in family meetings.

\section{Discussion}

One can suppose, that there are differences in ways in which the blue-, and white-collar workers spend their leisure time. It seems like the blue-collar workers, who are tired after an eight-hour work, more often choose the passive forms of relaxation, whereas the white-collar workers prefer the active recreation.

About 13\% of all workers surveyed did not have leisure time during the working days at all, and slightly more people had up to 1 hour of leisure time (23\%). During days free of fork, the white-collar workers had more leisure time - almost half of them had more than 6 hours of leisure time a day. One can suppose, that employees with children, especially the small ones and school-aged, have more responsibilities, and as a result, they have less leisure time compared to employees who are alone, childless, or have adult children. Another differentiating factor may be the place of residence of workers. Employees living in rural areas in private houses have more responsibilities, such as domestic care, and frequently farm work (Marcinkowski 2003).

The most frequently the surveyed employees spent their leisure time at home $(70 \%$ of the blue-collar workers, and $57 \%$ of the white-collar workers. The white-collar workers, who like spending their leisure time outside, spent it mainly in their place of residence (40\%), whereas the blue-collar workers - outside their place of residence $(20 \%)$.

The statistically significant differences between the groups surveyed occurred also in terms of preferences concerning forms of spending leisure time. The vast majority - $87 \%$ of the white-collar workers reported the fondness of tourism (the blue-collar workers - 57\%). The difference is visible also in the type of tourism. The blue-collar employees chose the recreational, and religious tourism, whereas the white-collar workers more often chose the qualified, and recreational tourism. Low popularity of skiing can be explained by the low level of the employees' advance in skiing, and its high costs (Kalecińska 2003).

Walks in the open air, cycling, swimming, working in the garden plots were the most popular types of active recreation both among the blue-collar- , and white-collar workers. Similar conclusions are presented in the research by Kalecińska (2003). Studying forms of the family recreation she stated, that although there is a diversity of recreational possibilities, walks (which were chosen by $74 \%$ of parents, and $46 \%$ of children), and cycling together are still the most popular among families. This fact is also proven in studies by Nałęcka (1996) and Janowska (1996).

Data from Table 4 indicate a certain regularity: definitely more white-collar workers chose different forms of spending leisure time - the blue-collar workers gave 71 votes, and the white-collar workers gave 117 votes. These results prove, that the white-collar workers prefer the active recreation. Half of the surveyed employees (from both groups), who show fondness of tourism, carried out qualified tourism activities a few times a year, and similarly frequently, or more rarely the recreational tourism.

Half of the white-collar workers indicated, that they like do-it-yourself activities, and other forms of amateur technical activities. It can be supposed, that employees tired of intellectual work prefer to perform do-it-yourself activities, as well as handicrafts.

The proportions are similar in comparison of both groups in terms of amateur breeding. Representatives of both groups were unanimous when it comes to their interest in the media. The majority declared that they use the Internet and watch TV for 1 hour a day. Nearly a half of the white-collar workers does not read the press, and every four person does not read books at all.

The similar tendency is visible among the blue-collar workers and the white-collar workers in terms of visiting cultural institutions. Every four employee goes to the theatre once a year, visits museums, or exhibitions, none of them goes to the philharmonic.

The approach towards parties and social contacts is completely different in the two groups. The blue-collar workers more willingly visit discos, and meet their friends (43\%). One can suppose, that they are tired of the monotonous work, frequently spending 8 hours face to face with a machine, look for a contact with other people. A similar frequency is observed in terms of visiting cafes, and clubs, as well as taking part in family meetings. 
These results of the survey were compared to the results of the study by Kacperczyk (2004), which concerned spending leisure time by the residents of Łódź, and results of the study by Dębski (2009) on spending leisure time by the residents of Trójmiasto. In the grup from Łódź, 83.8\% of people declared having leisure time, and $70.4 \%$ were not particularly satisfied with the way it was spent. The first of compared areas was the family life. For the residents of Łódź, family is the most important, and actually it was family (50.3\%), or a partner (21.1\%) with whom the surveyed spent their leisure time. they spent their leisure time on talking (57.1\%), or watching TV together. The results from Trójmiasto indicate, that $52.2 \%$ of people surveyed spent their leisure time with family, or with a partner. $45 \%$ of people surveyed needed about 3 hours daily for family and domestic responsibilities. When it comes to social life, one can establish that $57 \%$ of residents of Łódź spend their leisure time at home, and only $23 \%$ of respondents spend it in clubs, and restaurants. They take part in cultural events unwillingly $-78.9 \%$ of them does not visit philharmonic, $72.1 \%$ visits museum once a year, or less frequently, and $41.5 \%$ does not go to the theatre at all. Both residents of Łódź (72.1\%), and of Trójmiasto (68\%) declared having a hobby, and they the most frequently chose the cheapest ones. More importantly, residents of Łódź willingly performed touristic and recreational activities, however, the frequency of tourist travels in case of $55 \%$ was very rare - only once, or twice a year. The love for recreation was the most visible in cycling (among $28 \%$ of respondents).

According to the above mentioned results of surveys one can state that employees of Lajkonik from Skawina spend their leisure time in a similar way to the residents of Łódź, or Trójmiasto. The vast majority of them spends their leisure time at home with family, watching TV, or performing their hobbies, amateur artistic, or do-it-yourself activities. People who spend their leisure time outside their homes, refrain from visiting cultural institutions for the sake of recreation, or social life in clubs, and cafes.

On the other hand, studies of Andrzejewski and Posiadała (2003), carried out on the residents of Gniezno, answer the following question: what type of leisure do people prefer after work, and what factors influence their choice? It turned out, that the surveyed women and men at work declared, that they have leisure time only on non-working days. The amount of leisure time was influenced by their marital status, and family size. The more members of family, the less amount of leisure time. As many as $40 \%$ did not leave their place of residence while leisure time. The reason for that is the lack of funds, and family responsibilities. Respondents of that survey were more often relaxing at home and in the place of residence $(80 \%$ of the blue-collar workers, and $97 \%$ of the whitecollar workers). The most frequently mentioned forms of spending leisure time among the residents of Gniezno were sunbathing, and hiking. Respondents less often pointed out cycling, and sightseeing.

Only studies by Nowiccy (2003) indicate having much leisure time by respondents. However, such results are not surprising, because the survey was carried out on a group of unemployed women. Nearly $32 \%$ of them declared having from 2.1 to 3 hours of leisure time daily, and 31\% from 3.1 to 4 hours. Even though the amount of leisure time was significant, the women use it irrationally, because their opinions indicate their passive approach to active leisure and health care.

Groups of employees compared in this study did not differ in gender, age, marital or economic status, therefore one can assume that significant and less significant differences in answers (particularly on questions concerning forms of spending leisure time) most likely result from the character of performed job. The white-collar employees looked for relaxation in the active forms of leisure, and tourism, whereas the blue-collar employees preferred less active leisure, but they did not refrain from parties, and social contacts.

\section{Conclusions}

1. Respondents are stay-at-home type of people, they spend their leisure time most frequently with family.

2. The white-collar workers the most frequently chose active forms of leisure.

3. The white-collar workers carried out qualified and recreational tourism activities in their leisure time, whereas the blue-collar workers carried out the recreational and religious tourism activities.

4. The white-collar workers performed amateur artistic and do-it-yourself activities, as well as handiworks, breeding, and farming.

5. The blue-collar workers more frequently take part in parties, or social meetings.

\section{References:}

1. Andrzejewski M., Posiadała D. (2003), Czas wolny a formy wypoczynku mieszkańców Gniezna, W: W. Siwiński, R.D. Tauber, E. Mucha-Szajek (red.), Czas wolny, rekreacja, turystyka, żywienie (wyniki badań naukowych). Wyższa Szkoła Hotelarstwa i Gastronomii, Poznań, s. 95-105.

2. Baudrillard J. (2006), Społeczeństwo konsumpcyjne. Jego mity i struktura. Warszawa, s. 204-216. 
3. Bombol M., A. Dąbrowska A. (2003), Czas wolny. Konsument, rynek, marketing. K.E. Liber, Warszawa 2003.

4. Dębski M. (2009), Raport „Kultura spędzania czasu wolnego mieszkańców Trójmiasta”. Regionalne Centrum Wolontariatu w Gdańsku. Ex ANTE Kultura. Gdańsk.

5. Izdebska J. (1978), Czas wolny dzieci miejskich i wiejskich, W: Przecławski K. (red.), Czas wolny dzieci i młodzieży $w$ Polsce. Warszawa, s. 23.

6. Janowska M. (1996), Aktywność fizyczna w rodzinie w opinii rodziców, W: S. Arasymowicz (red.), Kultura fizyczna a rodzina. Materiały z Ogólnopolskiej Koferencji Naukowo-Metodycznej, Biała Podlaska, s. 56-60.

7. Jung B.H. (1989), Ekonomika czasu wolnego. Zarys problematyki, PWN Warszawa, s.6-7, 42.

8. Kacperczyk A. (2004), Czas wolny łodzian. Raport z badań. Uniwersytet Łódzki, Instytut Socjologii. Katedra Metod i Technik Badań Społecznych. Łódź.

9. Kalecińska J. (2003), Formy rodzinnej rekreacji. Wyniki badań, W: W. Siwiński, R.D. Tauber, E. Mucha-Szajek (red.), Czas wolny, rekreacja, turystyka, żywienie (wyniki badań naukowych). Wyższa Szkoła Hotelarstwa i Gastronomii, Poznań, s. 301-306.

10. Kamiński A. (1965), Czas wolny i jego problematyka społeczno-wychowawcza, Ossolineum Wrocław, s. 69-70, 148-200.

11. Kędzior J., Wawrzak-Chodaczek H. (2000). (red.) Czas wolny w różnych jego aspektach, Warszawa, s. 6-7.

12. Marcinkowski M. (2003), Zachowania wolnoczasowe wskaźnikiem jakości życia, W: W. Siwiński, R.D. Tauber, E. Mucha-Szajek (red.), Czas wolny, rekreacja, turystyka, żywienie (wyniki badań naukowych). Wyższa Szkoła Hotelarstwa i Gastronomii, Poznań, s. 79-87.

13. Nałęcka D. (1996), Rekreacja fizyczna i turystyka wśród innych form wykorzystania czasu wolnego w rodzinie, Roczniki Naukowe IWFiS, t. II, Biała Podlaska, s. 75-79.

14. Nowicki G., Nowicki R. (2003), Czas wolny, zdrowie i rekreacja fizyczna w opinii kobiet bezrobotnych, W: W. Siwiński, R.D. Tauber, E. Mucha-Szajek (red.), Czas wolny, rekreacja, turystyka, żywienie (wyniki badań naukowych). Wyższa Szkoła Hotelarstwa i Gastronomii, Poznań, s. 88-94

15. Przecławski K. (1993), Czas wolny dzieci i młodzieży, W: W. Pomykało (red.), Encyklopedia pedagogiczna. Warszawa, s. 75-76.

16. Ryłko A. (1989), Metody analizy statystycznej, AWF Kraków.

17. Winiarski R. (2011), Rekreacja i czas wolny. Oficyna Wydawnicza Łośgraf, Warszawa.

18. Wnuk-Lipiński E. (1972), Praca i wypoczynek w budżecie czasu, PAN Warszawa, s. 10-11.

19. Wolańska T. (1985), Rekreacja ruchowa w kulturze czasu wolnego. Wiedza o kulturze fizycznej, PTNKF Warszawa, s. 3-4. 